\title{
Analisis kadar zat besi pada sari kedelai kemasan dengan metode spektrofotometri UV-VIS
}

\author{
Reh Malem br Karo ${ }^{1}$, Jhon Patar Sinurat ${ }^{2 \star}$, Fioni ${ }^{1}$, Dewi Fibrini ${ }^{1}$ \\ ${ }^{1}$ Fakultas Kedokteran Universitas Prima Indonesia \\ ${ }^{2}$ Fakultas Farmasi Institut Kesehatan Medistra Lubuk Pakam
}

\begin{abstract}
ABSTRAK
Latar belakang: Kedelai adalah hasil pangan jenis kacang-kacangan yang sangat kaya akan nutrisi yang bermanfaat bagi kesehatan manusia. Tujuan: Untuk mengetahui keberadaan zat besi dan kadar zat besi dalam sari kedelai. Metode: Analisis kualitatif menggunakan pereaksi $\mathrm{NaOH}_{4} \mathrm{~K}_{4}\left[\mathrm{Fe}(\mathrm{CN})_{6}\right]$ dan $\mathrm{K}_{3}\left[\mathrm{Fe}(\mathrm{CN})_{6}\right]$ dan analisis kuantitatif menggunakan spektrofotometer UV-Visibel pada panjang gelombang $248.3 \mathrm{~nm}$. Hasil: Sari kedelai mengandung zat besi yang dibuktikan melalui analisis kualitatif menggunakan pereaksi $\mathrm{NaOH}$, $\mathrm{K} 4[\mathrm{Fe}(\mathrm{CN}) 6]$ dan $\mathrm{K} 3[\mathrm{Fe}(\mathrm{CN}) 6]$ yang menghasilkan masing-masing endapan hijau, biru dan coklat yang artinya mengnadung zat besi. Persamaan regresi linear larutan standar besi adalah $\mathrm{Y}=0.0154 \mathrm{x}+0.1555$ dengan korelasi (R2) sebesar 0.9981 . Kadar zat besi dalam sari kedelai adalah $56.48 \mathrm{mg} / \mathrm{ml}$ dan termasuk dalam kelompok produk yang memiliki kadar zat besi yang cukup tinggi. Kesimpulan: Sari kedelai mengandung zat zat besi dengan kadar sebesar $56.48 \mathrm{mg} / \mathrm{ml}$.
\end{abstract}

Kata kunci: sari kedelai, kadar zat besi, UV-Visibel

\begin{abstract}
Introduction: Soybean is a type of legume that is very rich in nutrients that are beneficial to human health. Objective: To determine the presence of iron and iron levels in soybean juice. Methods: Qualitative analysis using $\mathrm{NaOH}$, $K_{4}\left[\mathrm{Fe}(\mathrm{CN})_{6}\right]$ and $K_{3}\left[\mathrm{Fe}(\mathrm{CN})_{6}\right]$ reagents and quantitative analysis using $U V$-Visible spectrophotometer at a wavelength of $248.3 \mathrm{~nm}$. Result: Soybean juice contains iron which is proven through qualitative analysis using $\mathrm{NaOH}$, $K_{4}\left[\mathrm{Fe}(\mathrm{CN})_{6}\right]$ and $K_{3}\left[\mathrm{Fe}(\mathrm{CN})_{6}\right]$ reagents which produce green, blue and brown precipitates, which means they contain iron. . The linear regression equation for iron standard solution is $Y=0.0154 x+0.1555$ with a correlation (R2) of 0.9981 . The iron content in soybean juice is $56.48 \mathrm{mg} / \mathrm{ml}$ and is included in the group of products that have high levels of iron. Conclusion: Soybean juice contains iron with levels of $56.48 \mathrm{mg} / \mathrm{ml}$.
\end{abstract}

Keywords: soybean extract, iron content, $U V$-Visible

*Alamat korespondensi: jhonpatar12@gmail.com DOI: $10.34012 /$ jpms.v3i2.2038

\section{PENDAHULUAN}

Indonesia saat ini masih menghadapi tantangan dalam memenuhi tingkat gizi bagi makanan ataupun minuman yang dikonsumsi oleh penduduknya. Menurut Riset Kesehatan Dasar pada tahun 2018 menyatakan bahwa gizi buruk di Indonesia mencapai 3,9\% dan gizi kurang mencapai 13,8\%, sehingga secara total keseluruhannya adalah $17,7 \%$ dalam kelompok gizi rendah. Hal ini terjadi dikarenakan pola dan gaya hidup masyarakat yang lebih tertarik untuk mengkonsumsi makanan instan dan tidak antusias dalam mengkonsumsi buah dan sayuran. Hal ini dapat menyebabkan masyarakat rentan untuk terkena penyakit, salah satu nya adalah penyakit anemia yang terjadi karena mengalami kekurangan zat besi. ${ }^{1}$

Di dalam tubuh manusia, zat besi sangat bermanfaat dan memiliki banyak fungsi. Salah satu fungsinya adalah sebagai kofaktor enzim-enzim yang dalam reaksi redoks dalam proses respirasi. Zat besi memiliki peran didalam proses metabolisme energi sebagai pengangkut elektron. Pada hemoglobin 
terdapat sekitar $80 \%$ zat besi yang berfungsi untuk mengangkut oksigen dari paru ke seluruh tubuh dan membawa kembali karbondioksida dari jaringan ke paru-paru. ${ }^{2}$

Kedelai adalah hasil pangan jenis kacang-kacangan yang sangat kaya akan nutrisi yang bermanfaat bagi kesehatan manusia. Salah satu hasil pengolahan produk kedelai adalah sari kedelai yang tersedia dalam bentuk kemasan. Kandungan nutrisi dalam sari kedelai per $100 \mathrm{mg}$ yaitu 0,70 g/100 mg sementara susu sapi 1,70 g/100 mg. Sari kedelai dapat dijadikan sebagai alternatif khususnya bagi bayi maupun orang dewasa yang alergi terhadap susu sapi. ${ }^{3}$

Ada beberapa metode analisis yang dapat digunakan untuk menentukan kadar zat besi (Fe), salah satunya adalah metode Spektrofotometri UV-Visibel. Metode spektrofotometri UV-Visibel digunakan dalam menganalisis suatu sample secara kualitatif maupun kuantitatif. ${ }^{4}$ Berdasarkan paparean diatas, maka peneliti tertarik untuk melakukan analisis terhadap kadar Zat Besi (Fe) pada sari kedelai kemasan yang beredar di pasaran menggunakan Spektrofotometer UV-Visibel.

\section{METODE}

Bahan dan Peralatan

Bahan: Sari kedelai kemasan, $\mathrm{HNO}_{3}(\mathrm{p}), \mathrm{HCl}(\mathrm{p}), \mathrm{FeCl}_{3}, \mathrm{NaOH}, \mathrm{K}_{4}\left[\mathrm{Fe}(\mathrm{CN})_{6}\right], \mathrm{K}_{3}\left[\mathrm{Fe}(\mathrm{CN})_{6}\right]$, dan aquabidest. Peralatan: Spektrofotometer UV-Visible (Shimadzu 1800), hot plate, tanur, kertas saring Whatman no.42, Krus porselen.

\section{Analisis Kualitatif}

1. Tambahkan $\mathrm{NaOH} 1 \mathrm{M}$ beberapa tetes ke dalam $3 \mathrm{ml}$ sampel. Jika dihasilkan endapan putih yang teroksidasi menjadi endapan berwarna hijau kotor maka dinyatakan mengandung ion besi(ii) atau Fero $\left(\mathrm{Fe}^{2+}\right)$. Sementara jika hasilnya merupakan endapan coklat kemerahan maka dinyatakan mengandung ion besi(iii) atau Ferri $\left(\mathrm{Fe}^{3+}\right)$.

2. Tambahkan larutan $\mathrm{K}_{4}\left[\mathrm{Fe}(\mathrm{CN})_{6}\right]$ ke dalam $3 \mathrm{ml}$ sampel sehingga akan terbentuk warna biru tua jika mengandung zat besi.

3. Tambahkan larutan $\mathrm{K}_{3}\left[\mathrm{Fe}(\mathrm{CN})_{6}\right]$ ke dalam $3 \mathrm{ml}$ sampel sehingga akan terbentuk warna cokelat jika mengandung zat besi.

\section{Analisis Kuantitatif}

1. Destruksi Sampel

Sari kedelai ditimbang sebanyak $1 \mathrm{~g}$, kemudian dimasukkan ke dalam erlenmeyer $100 \mathrm{~mL}$ dan ditambahkan $30 \mathrm{~mL} \mathrm{HNO}_{3}$ pekat, larutan didiamkan selama 15 menit. Selanjutnya dipanaskan selama 15 menit di atas hot plate. Pemanasan diteruskan hingga volume $\mathrm{HNO}_{3}$ 1,5-3 mL atau sampel mulai kering namun belum terbentuk arang, kemudian sampel ditambah $\mathrm{HCl}$ pekat sebanyak $25 \mathrm{~mL}$ dan dipanaskan kembali selama 15 menit hingga terbentuk gas klorida, pemanasan ditingkatkan sampai sisa volume 3-5 mL, sampel mendidih dilarutkan dengan 10 $\mathrm{mL}$ aquabidest, diaduk dan dituangkan ke dalam labu ukur $25 \mathrm{~mL}$, Erlenmeyer dibilas dengan $5 \mathrm{~mL}$ aquabidest dan larutan diencerkan sampai tanda batas.

2. Pembuatan Kurva Kalibrasi Zat Besi (Fe)

Pembuatan larutan induk Besi (Fe) sebesar 1000 ppm yang dibuat dari $100 \mathrm{mg}$ dalam $100 \mathrm{ml}$ pelarut. Kemudian diencerkan hingga diperoleh larutan standar logam Fe 100 ppm. Larutan standar diambil sebanyak masing-masing 2.5; 5.0; 7.5; 10 dan $12.5 \mathrm{~mL}$ dan dicukupkan dengan $\mathrm{HNO}_{3}$ 0,1 N hingga 50,0 mL. Larutan standar logam Fe (5, 10, 15, 20 dan 25 ppm) ditentukan absorbansinya dalam Spektrofotometer Uv-Vis pada panjang gelombang 248,3 nm. 
HASIL

Analisis Kualitatif

Analisis kualitatif dilakukan sebagai analisis pendahuluan untuk mendeteksi keberadaan zat besi dalam sampel sari kedelai.Hasil analisis kualitatif berupa pereaksi dan perubahanya ditampilkan pada tabel 1.

Tabel 1. Hasil analisis kualitatif zat besi dalam sari kadelai

$\begin{array}{cccc}\text { Sampel } & \text { Pereaksi } & \text { Hasil Reaksi } & \text { Hasil } \\ \text { Sari Kedelai } & \mathrm{NaOH} 1 \mathrm{M} & \text { Endapan Putih } \rightarrow \text { Hijau Kotor } & + \\ \text { Kemasan } & \mathrm{K}_{4}\left[\mathrm{Fe}(\mathrm{CN})_{6}\right] & \text { Biru } & + \\ & \mathrm{K}_{3}\left[\mathrm{Fe}(\mathrm{CN})_{6}\right], & \text { Coklat } & +\end{array}$

\section{Analisis Kuantitatif}

Kurva kalibrasi zat besi diperoleh melalui pengukuran absorbansi larutan standar zat besi pada panjang gelombang $248 \mathrm{~nm}$. Persamaan regresi linear yang diperoleh yaitu $\mathrm{Y}=0.0154 \mathrm{x}+0.1555$ dengan korelasi $\left(\mathrm{R}^{2}\right)$ sebesar 0.9981. Kurva kalibrasi ditampilkan pada gambar 1.

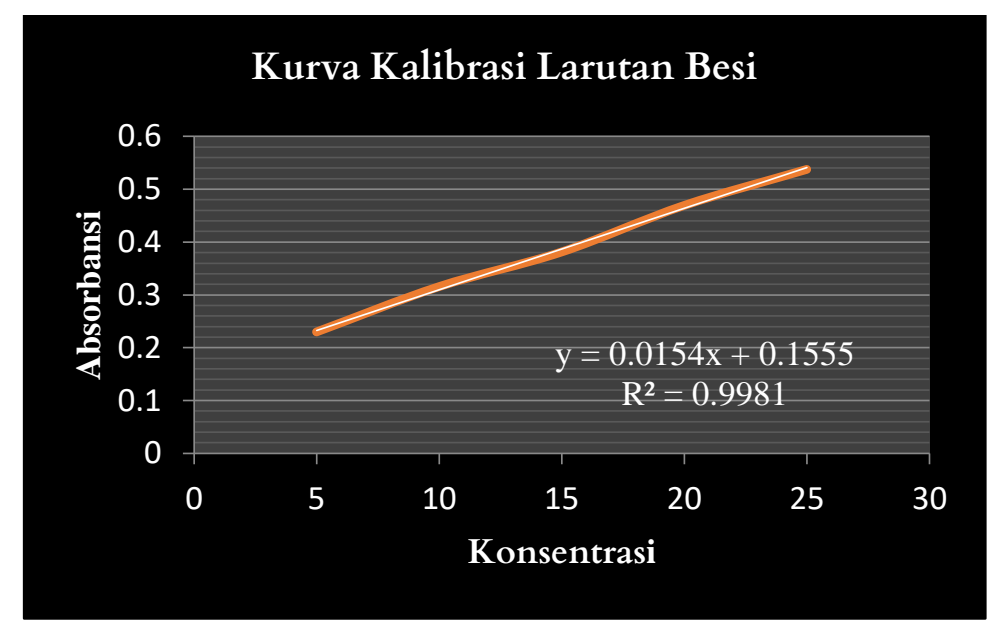

Gambar 1. Kurva Kalibrasi Zat Besi

Penetapan kadar zat besi pada sari kedelai dilakukan sebanyak 3 kali pengulangan, dengan tujuan untuk hasil pengukuran absorbansi yang lebih teliti sehingga persen kesalahan dapat diminimalisir sehingga diperoleh kadar zat besi dalam sari kedelai adalah sebesar $56.48 \mathrm{mg} / \mathrm{mL}$.

Tabel 2. Kadar zat besi dalam sari kedelai

$\begin{array}{lc}\text { Kadar Zat Besi Sari Kedelai } & \text { Kadar Rata-Rata } \\ 56.38 & \\ 56.57 & 56.48 \\ 56.49 & \end{array}$

\section{PEMBAHASAN}

Hasil analisis kualitatif yang menimbulkan munculnya beberapa endapan dan larutan berwarna menunjukkan terjadinya reaksi kimia antara zat besi dalam sari kedelai dengan pereaksi yang digunakan dalam analisis ini seperti ditampilkan reaksi-reaksi berikut:

Reaksi Kimia :

$$
\begin{aligned}
& \mathrm{Fe}^{3+}+3 \mathrm{NaOH} \rightarrow \mathrm{Fe}(\mathrm{OH})_{3}+3 \mathrm{Na} \\
& \mathrm{Fe}^{3+}+\left[\mathrm{Fe}(\mathrm{CN})_{6}\right]^{3-} \rightarrow \mathrm{Fe}\left[\mathrm{Fe}(\mathrm{CN})_{6}\right]
\end{aligned}
$$




$$
4 \mathrm{Fe}^{3+}+3\left[\mathrm{Fe}(\mathrm{CN})_{6}\right]^{4-}->\mathrm{Fe}_{4}\left[\mathrm{Fe}(\mathrm{CN})_{6}\right]_{3}
$$

Kadar zat besi pada sampel sari kedelai sebesar sebesar $56.48 \mathrm{mg} / \mathrm{mL}$. Faktor yang menyebabkan kadar zat besi pada sari kedelai kemasan lebih kecil yaitu karena adanya proses penambahan komponen lain dalam komposisi sari kedelai kemasan seperti air dan gula.Manusia normal membutuhkan sekitar 20-25 mg zat besi per hari untuk memproduksi sel darah merah. Diperkirakan jumlah besi yang dikeluarkan tubuh sekitar 1,0 mg/hari, untuk wanita ditambah 0,5 mg hilang karena mentruasi. Dalam memenuhi kebutuhan zat besi, seseorang biasanya mengkonsumsi suplemen, akan tetapi salah satu alternatif untuk memenuhi kebutuhan zat besi dapat dilakukan dengan mengonsumsi makanan yang mengandung zat besi contohnya kacang kedelai atau sari kedelai kemasan. ${ }^{5}$

\section{KESIMPULAN}

Sari kedelai mengandung zat besi yang dibuktikan melalui analisis kualitatif menggunakan pereaksi $\mathrm{NaOH}_{4} \mathrm{~K}_{4}\left[\mathrm{Fe}(\mathrm{CN})_{6}\right]$ dan $\mathrm{K}_{3}\left[\mathrm{Fe}(\mathrm{CN})_{6}\right]$. Persamaan regresi linear larutan standar besi adalah $\mathrm{Y}$ $=0.0154 \mathrm{x}+0.1555$ dengan korelasi $\left(\mathrm{R}^{2}\right)$ sebesar 0.9981 . Kadar zat besi dalam sari kedelai adalah 56.48 $\mathrm{mg} / \mathrm{ml}$ dan termasuk dalam kelompok produk yang memiliki kadar zat besi yang cukup tinggi.

\section{REFERENSI}

1. Kementerian Kesehatan. 2018. Riset Kesehatan Dasar 2018. Badan Penelitian dan Pengembangan Kesehatan Kementerian.

2. Paputungun SR, Kapantow NH, Rattu AJM. Hubungan Asupan Zat Besi dan Protein Dengan Anemia Pada Siswa Kelas VIII dan IX di SMPN 8 Manado. Pharmacon Vol.5 No.1:2016

3. Rohmani S, Yogatama A, Prihapsara F. Innovations Healthy Drinks in Source of Soybean in Community Empowerment through Entrepreneurship in Sukoharjo District. Agrokreatif Jurnal Ilmiah Pengabdian Kepada Masyarakat, Vol.4 No.1:2018

4. Putri MP, Setiawati YH. 2015. Analisis Kadar Vitamin C Pada Buah Nanas Segar (Ananas comosus (L.) Merr) dan Buah Nanas Kaleng Dengan Metode Spektrofotometri UV-VIS. Jurnal Wiyata, Vol.2 No.1:2015

5. Amin F, Zulys A, Bakri R. Fortifikasi Dan Ketersediaan Zat Besi Pada Bahan Pangan Berbasis Kedelai Menggunakanbesi Edta, Glisinat, Fumarat, dan Suksinat. Jurnal Itekima, Vol.1 No.1: 2017 